\title{
光線による眼の障碍
}

京都帝國大學数授 市 川 清

\section{The Disturbances of Eye by Light.}

By Prof. K. Ichikawa.

(Ophtomological Clinic, Kyoto Imperial University)

\section{内 容 梗概}

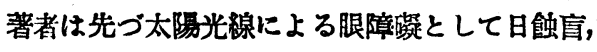
虹親症，雪盲，春季加答兒，飛行家に來る網膜疾患 白內蹱( ? )双た人工光源上り發与る光線によるもの そして電氣性眼炎，硝子職工に見らる今白內障等を 列擧したる後，如何なる光線が眼に對して有害なる かの問題に就きては, 光線の量よりも光線の性質か 重要なる關係を有し，一定の波長領域內の光線は眼
組織の一定の部位を搇擇的に犯すあのなることを述 ベ, 從來交献に 記載せられたる 既知の 事實の外, $360-310 \mu . \mu$. 波長領域內の光線力嫁鬼眼網膜を能く

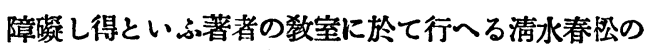
實驗を紹介せり。向最後に著者は此等眼障礙に對す る眼の保護に就き論及し, 諸種の硝子の有する短波 光線吸收能力を锐示せり。(自抄)

\section{Synopsis.}

The author mentions eclipse-blindness, erythropsia, snowblindness, conjunctivitis vernalis, retinal diseases among aviators, and cataract (?) as disturbance of eye by sunlight. He also exemplifies electric ophthalmia and glassworker's cataract etc. as one occurring by irritation of artificial light. Then as to the problem what ray acts harmful against eye, the author lays more stress upon the qualities of ray than upon the quantities. He states that light within a certain limit of wave-length excites electically a certain part of eye-tissues and besides known facts described in the old literatures, he introduces an experiment worked by Dr. Shimizu performed under the author's direction that the light within $360-310 \mu . \mu$. wave-length disturbs readily the retina of rabbit's eye.

The author finally discusses on the protection of eye against these eyediseases and also explains bingability of various kinds of glasses of shortwave ray.

今夕ての集りで講演を致します事は, 私の最も光榮とする所で御座るます。私の講演は光線に よる眼の障碍に就てでありまして，次の順序によつて御話申し上げます。

\section{[1]太陽光線による眼の疾病}

\section{[2]人工光線より發する光線による疾㾈}

〔3] 如何なる光線が眼に有害なるか

\section{〔4〕有害光線に對する眼の保護}

〔1〕先づ第一の太陽光線による眼の疾病に就て御話致します。

一體光線が眼に對して有害作用を及ばす事に就ては，おつと以前には餘り考へられて居なかつ たので御座みまして，學者の注意を惹く樣になりましたの良近の事であります。以前の樣に石

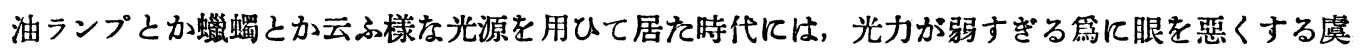
れが無いのであら5かと云ふ事が, 近視の問題と關聯して學者の議淪する所となつて居りました が，近頃は之に反して光力が强過ざる事が人ょの不安を起させる事になりました。之は近來人工 
光線の長足の發澾に起因して居る事は刎論であります。

さて太陽光線による眼の疾病として知られて居るものは相當たくさんあります。そのうちで太 陽の直射光線を見を時に矓く感ずる事も眼に對する障害でありますが，古くから知られてるる疾 病であつて，而も人の注意を惹んて居るのは雪盲之云ふ病氣であります。之は雪の積つて居る路 を長い間旅行した場合に起りますので，その症狀は劇しい結膜炎でありまして，眼が赤くなり， 淚や目脂が出まして，又眼が痛んで長い間眼を開して居る事が出來にくくなります。ての雪盲は 光線中の紫外線による障害であら5と云ふ事は, 古くから人の想像して居る所であります。

夾に太陽光線による眼の疾病として知られて居るのに日蝕盲と云ふ病氣があります。日蝕の時 几裸眼で太陽を長い間見つめて居ると, それが䉆に疾患が起ります。今眼の構造をざつと書いて 見ますと圖の樣になります。日蝕盲てか」りますと，網 膜の眞中の, 最も大事な役をして居る, そして少し黃色 を帶びた黄斑部と云はれて居る部分に變化が起ります。 丁度視界の中央郎ち固祝點に相當して，見えにくん部分 が起ります。郎ち最も銳敏に見なければならない所に障 害が起るのであります。無論その䉆視力障害が起つて見 えにくくなります。ての視力障害の程度は, 健康な人の 三分の一位に視力が減退して，多くは永久に治りません。 之は日蝕の時に限ら热本時に於ても太陽を長い間見つめ てなると起り得るのであります。日触の時に霬々起りま すから日蝕盲と申します。

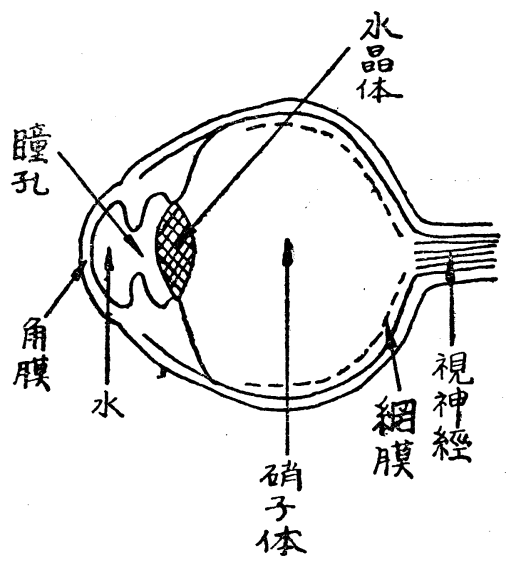

次に太陽光線による疾病として知られて居ります病氣に紅視症と云ふ病氣があります。之の症 狀は白レ物が赤く見え，灰色の物が綠色に見える，郎ち色感に變狀が起るのですります。長い間 雪路を行軍した樣な場合汇起ります。ての病氣は又人間の眼から水晶體を手術により取り去つた 場合, 或は瞳孔が散大してるる場合に好んで起ります。之も網膜の障害によるものと考へられて 居ります。

次に太陽光線による疾病として知られて居ります病氮として, 春季加答兒と云ふ疾患がありま す。ての病氣は若い人に多?，五六才から三十才前後の人に起ります。その症狀は瞼の重に一種 のトラホームの時に見る樣な粒くが出來, 多少目脂が出て, 眼が大變かゆく, 特有な點は之にか ১ると, 泰から夏に亘つて症狀が劇しくなり，秋より冬にかけて，自然によくなります事で，て んな事を每年繰返し三十才頃になると自然に治ります。郎ち季候と密接な關係があります事から 光線病であると考へられて居ります。ての病氣は誰でもかいると云ふ事なく，之にか小り易い素 質を持つた人に起ります。

次に太陽光線による疾病として知られて居ります病氣は, 飛行機の發達につれて起つた病氣で ありますが，之は長い間飛行に從事して居る飛行家に起るのであります。やはり視力障害が起る のであります。前に述べました日蝕盲の場合には，黃斑部がおかされますのでての時には中心暗 
點が生じたと申しますが，飛行家の眼疾患に於ては輪狀暗點が起るのであります。郎ち硯野の真 中に近い所に輪の樣になつて見えにくい所が起ります。高地に於ては低地に於てよりる紫外線が 多いるのですから，高空を飛ぶ飛行家にての樣な疾患が起るのであら5と考へられて居ります。 头に白內障と云ふ㾈氣が御座わます。之は俗にウミンコヒと申して居ります。之は水晶體が混 濁して白くなるのでありまして，その當然の結果として視力障碍が起ります。之も太陽光線によ る障碍であら5之唱へて居る學者があります。之が光線による障碍であると云ふ說の根據は次に 迅へろる如くであります。筫驗的に動物の眼に紫外線を長い間あてるとての白內障が起ります。及 硝子工場で硝子を吹く職工が長い間硝子工場で働くと同じ樣な白內障の应狀が起ります。てれは

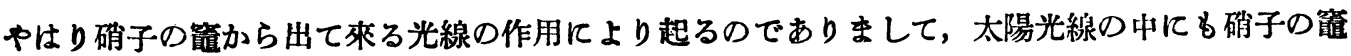
から出る光と同じ光が出て之が白內障を起すのであらうと考へられて居ります。刃白內障は多く 水晶體の下の方の部分から混濁が始まるものでありまして，之も一つの根據となつて居ります。 と云ひますのは太陽の直射光線は多く眼の下の方に作用する篇飞水晶體の下の方の部分から混濁 が起るのであららと想像されるからであります。

次に日本で或學者が唱へて居る眼の疾患に，脚氣弱視と云子病氣があります。之も光線障害に よるのであら5と，唱へて居る人があります。脚氣にか」ると增感物質郎ち光に對して敏感なら しめる物質が身體の中に出來て，この物質が太陽光線に有害に作用してての病氣を起すのであら らと考へられて居ります。ての說はまだ充分の根據がありません。と云ひますのはての病氣が光 線障害でありますならば網膜が最初冒される筈でありますが，ての病氣は網膜は周されすに，視 神經が冒されるのであります。

次に眼の病氣ではありませんが，皮膚病にペラグラと云ふ病氣があります。ての疾患は玉蜀系 を多食する人に起ります。ての病氣にからりますと，皮席に赤い斑點が出來ます。ての斑點は着 物で蔽はれて居ない部分にのみ起ります。郎ち光線に暴露されて居る所にのみ起りますから，光 線病であら5之考へられて居ります。之は玉蜀㯟を食べた第に增感物質が出來て之が爲に, 光線 が作用した所にての症狀が起るのであららと考へられて居ります。身體の中に增感物質が出來る と光線の作用が增大される事は面白い事でありまして，ての事は治療にも應用せられて居りま ナ。眼の結核の治療には增感物質を附與して光を作用さすとその効果が多いのであります。それ にはフルオレッチェン加里の $2 \%$ の溶液, 或はエオジンと云ふ色素を點眼して, 光線を作用せし めますとよくなります。ての事から考へて增感物質が體內にある事は, 光線病に對する素因を增 大する事になります。

要するに太陽光線による眼の障害は何れる普通の條件に於て起る事なく，長い間空中を飛行す るとか, 長い間雪の中を旅行するとか云ふ樣な特殊な場合に起るるのであります。但し增感物質 が體內にあるならば, 普通の狀態に於ても病氣が起ります。

〔1]次に第二ノ人工光源より墢する光線による疾病に就て申し上げます。

人工光源より墢する光線による疾病は甚炿少ないのであります。と云ひますのは吾くは始終太 陽光線の作用を蒙る機會が多くありますが，人工光線ならば太陽光線にくらべて作用を蒙る機會 
が少いからであります。然し人工光線は太陽光線て比へて人の眼て及传す effect は恐らく大であ ら5と想像されます。何故なれば强い人工光線を見つめますと，その人工光線つ光力は太陽光線 のそれに比べて大變弱いにも拘らず，太陽光線よりももつと强い不快の感や痛みを與へるのです りますからての點より考へてもし人エ.光線が太陽光線と同じ狀態で作用したならば恐らくもつ と害が大であららと思はれます。

人工光線による疾病として今日迄知られてるる病氣は電氣性眼炎であります。之は一種の結膜 炎でありまして, 光力の强い電登とか弧燈の下で暴露されて居ると, 劇しい結膜炎が起つて，眼 が赤くなり，淚や目脂が出て，眼が痛みます。即ち雪盲と症跃が大變よく似て居ります。この病 氣は活動の俳優とか, 電車線路で電鐵の工事をして居る職工に起ります。後者の疾患は鐵之鐵之 をつなぎ合す時に出る Eisenlight 中の强い紫外線によつて起るのであります。又それを傍觀し て居た人にも起ります。ての病茶の性質は惡くなく，數日間眼を冷せばよくなりますが，一旦か

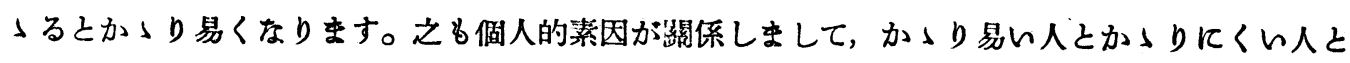
あります。

も一つ昔から人の注意して居るのは, 硝子吹をて見る白內障であります。無諭硝子工場に長い 間働いて居る職工に起るので，水晶體が混溜して，視力が減退㮹します。ての混濁をとらない限 り, 視力沬回復致しません。面白い事は白內障にか」る職工は, 白內障にのみか」り, 他の結膜 の疾患にかりる事がないと云ふ事で御座みます。

人工光線による疾病は，あまり數多くなく，僅かに今述べした二つで御座るますが，之も特 殊の場合にのみ起りまして，普通の條件のもとには起りません。

〔3〕次に第三の如何なる光線が眼に有害なるかに就て述へませう。

以上述べしした樣に, 光線に依る眼の疾患山其の種類相當多く, おかされる部分も夫ぇ異つて 居ます。郎ち結膜, 角膜, 水晶體, 網膜等色々です。此のてとから推して考へると, 光線て依る 眼の障碍は其の光力の如何よりも，其の種類が主として關係すると云へます。郎ち或る特殊の光 線が眼の異る部分を撰擇的に侵すのです。然らば如何なる種類の光線が眼に有害なるかを定める ネは、二つの研究方法があります。

1. 人工光線或は太陽光線を水晶つプリズムで分光し，特殊の滤過裝置で滤過し，一定の波長領 域のものをより出し，動物の眼に作用させ，如何なる變化が起るかを調くるのです。

2. 眼の色 くの部分即ち角膜, 網膜, 水晶體, 硝子體等光の通過する中間體の一部分を一つ一つ 取出し，それらのるのがスペクトラムの中の如何なるものを吸收するかを調べるのです。光 線が此の樣な組織に對して有害なるはそれに光線が吸收されるからで，吸收の起らない處に は障碍は起りません。それですから吸收能力を調へると，何れの光線が眼の何れの部分に惡 レから゙わかります。

此の樣な方法で多くの人が研究しましたが，其の中で明になつたととを申しますと，光線の中 で $760 \mu \mu-400 \mu \mu$ の範圍の光線, 即ち所謂可視光線は眼の中間體郎ち角膜, 硝子體には吸收さ れずて網膜に達し，何等有害ではすりません。400 $\mu$ 以以下波長つ光線郎ち紫外線の中でる， 
$300 \mu \mu$ 以下のものは觕膜に吸收されます。角膜は此の短波長光線を吸收する能力を持つて居る のです。 $400 \mu \mu-300 \mu \mu$ の波長の光線は水晶體に吸收されるので, 水晶體は此の間の波長の光 線を吸收するの能力を持つて居ると云へます。故に角膜, 結膜に有害なる光線郎ち雪盲, 電氣性 眼炎を起すのは， $300 \mu \mu$ 以下の紫外線であります。そして $400 \mu \mu-300 \mu \mu$ の光線は白內障を 起す光線であります。Cramer 比は實際調查の結果, 硝子工場の篒から出る光線中には, $400 \mu \mu$ -300 $\mu \mu$ の光線が最も多く含まれて居ると云つて居ます。 $400 \mu \mu$ 以下の紫外線恃, 其の一部分 は角膜に, 他の一部分は水晶體に吸收されるから, 郎ち紫外線はすつかり吸收され網膜には涬し ないことつなります。此の樣に申しますれば網膜は紫外線の有害作用を蒙らないてとつなります が，何時もさらではありません。水晶體の紫外線に對する吸收能力は各人に於て異り，年龄に依 りても變り，及一般動物にありては其の種類に依つて夫ふ違つて居ます。故に人間の眼でも400 $\mu \mu-300 \mu \mu$ の範圍の光は, 時として網膜に達するてとがあります。佾紫外線は有害で可視線は 有害でないと申しましても，此の兩者の間には制然たる境があるわけではすりませんから，此の 中間に位する漾な波長の光線は網膜に達し，其の量が多いとをは有害となります。私の呚空つ淸 水氏の實驗倿りますと，鬼の眼に $360 \mu \mu-310 \mu \mu$ 內の紫外線を十分間あてますと，其の眼は 炎症を起します。鬼の眼の水晶體は人間の眼のそれょり吸收能力が少いから，人間より網膜の侵 されることが多いわけであります。恐らく日蝕目は此の漾にして網膜に達した紫外線に依り發し た障碍でせ5。

以上は $400 \mu \mu$ 以下の波長の光線に就て述べたのですが, $760 \mu \mu$ 以上の長波長のもの郎ち赤 外線は如何と云ふれ，それも亦有害であります。一昨年の Bücker 氏の筫驗成績に依りますと， 赤外線に長時間さらされると角膜, 水晶體, 網膜に變化が起きます。故に赤外線も有害ですが, 此のてとは實驗的には證明されても普通の場合稀であります。と云ふのは人工光線から赤外線が 出て目を害するてとは，普通の條件の下には起らないからです。

以上述べました梯に私等の腿に害を與へるの主として紫外線でして, 波長が異ると共て撰摆 的に働を，一定の波長のものが眼の一定の部分に障碍を與へます。

[4]次に第四の光線有害作用に對する眼つ保護に就を述べれんと思ひます。以上の様に我々の 眼に有害作用を䉆すのは主として紫外線で，而もそれは通常の條件の下で起きす特殊の條件の下 におきます。殊に人間が特殊の素因を有する場合或は增感物質を持つとをに，紫外線は有害作用 它與へます。故に之に對する眼の保護は, 紫外線が眼に入らない樣にすれば良いわけですります。 即ち飛行家，旅行家，敢工，紫外線の研究者には之れを防ぐべを眼鏡が必要であります。刃紫外 線を發する樣な光源の周圍には，之れを吸收する樣な蔽ひを置くべをであります。人工光線の中 蠟蠋，石油ランプの光の中には紫外線は殆んどありません。アセチレン瓦斯や電燈の光は透明な 硝子で蔽はれるとさ赤外線はありますが， $300 \mu \mu$ 以下の紫外線を含むてとは少く，又鐵弧燈， 炭素弧燈中には $300 \mu \mu$ 以下の波長が多量に含まれます。此の樣な光源中の紫外線を除くには, 之れを四收し易き硝子で蔽ひ，又人は眼鏡をかける必要があります。

眼鏡の硝子は普通のクラウン硝子でも紫外線を吸收しますが，而し其の能力は僅です。厚さ 
が5すい硝子は $300 \mu \mu$ 以下の波長は四收せず, $300 \mu \mu$ 以下の光線が吸收される爲めには, Schanz 氏几依ると $18 \mathrm{~mm}$ の厚さの硝子が必要です。此の爲めに特殊硝子が必要となつて來る のでして, 米國のクルツク硝子. 獨乙のオイホス硝子 (Euphos glas), 理研のウルトラジン第一 號(Ultrasin 1) 等は此の目的に向つて有効なものです。私の敉室で之れらの硝子の吸收能力を比 較して見ましたが，其の結果次の樣です。

$\begin{array}{ll}\text { Euphos glas } & 360 \mu \mu \text { 以下吸收 } \\ \text { Ultrasin 1 } & 460 \mu \mu \quad " \\ \text { Uviol glas } & 270 \mu \mu \quad \text { " } \\ \text { Crook } & 360 \mu \mu\end{array}$

之れで見ますれば理研のウルトラジン第一躆は最もよろしい。それで紫外線に對して眼を保護 する樣な目的て向つては，之れを用ふのが最も有効となります。

私の話しは之れで了ります。つまらぬ話に永らく御靜聽を煩しましたてとを感謝致します。

\section{質問 應 答}

本 野 會 長。唯今の御雎演に就きまして御質問御意見がありますならば，何卒御遠虑なく御述 べ下さレ。

松田長三郎君。紫外線の吸收能力の測定は如何にして行はれますか。

市川 清君。例へば角膜を取りて水晶板の間にはさみ, 之れに光線を通しスベクトログラフを とりました。

松田長三郎君。石英燈からは中々多くの紫外線が出ますが，實驗室で之れを觀察します際に色々 の硝子を通して見ますと，其の現象がはつをりしませんので，時々裸眼で觀察して眼を痛め るととがありますが之れは何時までも續くものでせうか。

市川 清君。それは直きに好くなります。

松田長三郎君。又鐵などの電氣鎔接をする場合などでも强烈な紫外線が出ますが此等も同樣に永 久的障碍とはならないでせらか。

市川 淸沼。永久的な障碍は起しませんが，か〉り易くなります。動物試驗を行ひまして，角 膜に紫外線を一度あてますと，二度目からはそれ程强を光線をすてなくとも始めの樣な烈し い障碍を起します。

松田長三郎君。活動寫訔撮影の時には炭素弧燈を用ひまして, 俳優は非常に强烈な光に照される

ことがあります。其の際頙面皮膚が非常に荒され, 眼も初めの中はいたみますが, 後には何

ともないと申します。此の樣な障碍は蓄積されて琹くなると云ふ梯なととはないでせうか。

市川 清君。撮影のとをは裸燈を用ひますか。

松田長三郎君。裸燈を用ふるか，或はヂェラチン紙を前に置くことがあります。

市川 清君。裸燈でなければいけないのですか。

松田長三郎君。diffused light を得る曘めには裸燈ではいけないので普通此の方法を用してるる 
やらです。

市川 清君。理研の Uitrasin 1 は色が濃からず光力を弱めることが少いから餘程良いでせう。 本 野 亨君。水晶體は自然几紫外線を吸ひ，網膜に障礙を與へない樣になつては居ませんか。 市川清君。水晶體は紫外線の一部を吸收しますが，その主なる役目は明瞭な像を網膜上几結 ばせるための調節作用です。

本 野 亨君。紫外線の防锤作用はないのですね。

市川 清君。さうです。特に其の機能を持つては居るといふ譯ではすりません。但角膜, 水晶 體は大部分の紫外線を吸收する能力を持つて居ます。

本 野 亭君。光は凝視しなければ害はありませんか。 市川 清君。凝視しなくとも時間が永ければ害はあり得るわけです。雪盲の如きその一例です。 會長(本野亭君)。今日は市川博士には御遠方の處をお出で下さいまして, 吾々の爲めに誠に有益 なお話しを懇切に，專門外の吾々にも了解出來る樣にお話し下され有難ら御座るました。皆

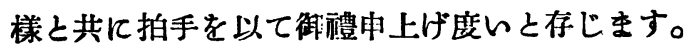
〔拍
手]

では今夕は之れで閉會致します。 